\title{
Thermal Stability and Conductivity of Carbon Nanotube Nanofluid using Xanthan Gum as Surfactant
}

\author{
(Kestabilan Termal dan Kekonduksian Bendalir Nano Karbon Tiub Nano
} menggunakan Gam Xantan sebagai Surfaktan)

\author{
Saba Rashidi*, RASHMi, W., LUQMAN CHUAH ABDUllah, KHALid, M., \\ FAKHRUL-RAZI AHMADUN \& M.Y.FAIZAH
}

\begin{abstract}
A nanofluid is a suspension of nano-sized particles dispersed in a base fluid. It is very much obligatory to know more about stability and thermal characteristics of such a nanofluid for their further use in practical applications. In this research, multiwalled carbon nanotubes (CNT) is dispersed in water. CNT dispersed in water is highly unstable and it sediments rapidly due to the Vander Waals force of attraction. Therefore, to overcome this limitation, xanthan gum (XG) was added which behave as a promising dispersant followed by $4 \mathrm{~h}$ water bath sonication. Experimental work includes stability studies using UV Vis spectroscopy with respect to CNT concentration (0.01 and $0.1 \mathrm{wt} . \%)$ and XG concentration $(0.04$ and $0.2 w t . \%)$. The thermal conductivity of the most stable suspensions was measured using KD 2 Pro as a function of temperature $\left(25-70^{\circ} \mathrm{C}\right)$ and $C N T$ concentration. The optimum $X G$ concentration was found for each CNT concentration studied. Thermal conductivity was observed to be strongly dependent on temperature and CNT concentration. The dispersion state of the CNT-water nanofluid is further examined using scanning electron microscope (SEM). In short, CNT nanofluids are found to be more suitable for heat transfer applications in many industries due to their enhanced thermal conductivity property. This work provides useful insight on the behavior of CNT nanofluids.
\end{abstract}

Keywords: Carbon nanotubes; nanofluid; stability; thermal conductivity; xanthan gum

\section{ABSTRAK}

Bendalir nano ialah penggantungan zarah bersaiz nano dalam bendalir asas. Adalah sangat penting untuk mengetahui lebih lanjut tentang kestabilan dan pencirian termal daripada bendalir nano tersebut bagi tujuan kegunaan praktik selanjutnya. Dalam kajian ini, pelbagai lapisan karbon tiub nano (CNT) terserak di dalam air. Penyerakan CNT ini tidak stabil dan endapan berlaku dengan pantas kerana adanya daya tarikan Vander Waals. Oleh itu, bahan sampingan gam xantan $(X G)$ telah digunakan dalam kajian ini sebagai agen serakan. Penyelidikan bagi mengkaji kesan kepekatan CNT (0.01 dan 0.1 wt. \%), kepekatan XG (0.04 dan 0.2 wt.\%) dan masa sonikasi (4 jam) ke atas kestabilan bendalir nano telah dijalankan. Bacaan kestabilan diambil dengan menggunakan spektrofotometer UV-Vis. Termal konduktiviti yang paling stabil telah diukur sebagai fungsi suhu $\left(25-70^{\circ} \mathrm{C}\right)$ dan kepekatan CNT. Bendalir nano didapati tidak stabil pada sonikasi selama 4 jam dan kepekatan optimum XG didapati antara 0.04,0.2 \% bt. dan 0.01,0.1\% bt. bagi julat kepekatan CNT yang dikaji. Pemerhatian menunjukkan bahawa, konduktiviti termal amat bergantung kepada suhu dan kepekatan CNT. Keputusan mendapati CNT bendalir nano adalah lebih sesuai untuk aplikasi pemindahan haba dalam pelbagai industri kerana adanya peningkatan sifat konduktiviti termal. Kajian ini menyediakan maklumat mengenai sifat CNT nano bendalir.

Kata kunci: Bendalir nano; karbon tiub nano; kestabilan; konduktiviti termal; gam xantan

\section{INTRODUCTION}

Several techniques have been suggested to increase the heat transfer performance of fluids in order to achieve smaller heat transfer systems with improved energy efficiencies and lower capital costs. Maxwell (1954) suggested utilizing micro-sized suspensions instead of common heat transport liquids due to higher thermal conductivity of solids compared to liquids. However, micro-sized particles pose many difficulties, such as higher pumping power requirement, sedimentation of particles and erosion of transport equipment. In order to overcome these limitations, 'Nanofluid' suspensions can be used that contains dispersed nano sized particles (Choi \& Eastman 1995). Nanoparticles are very small particles (nanometer size) and based on the Stokes theory, nanofluids demonstrate higher stability than common suspensions. In addition the transport fluids require less pumping power and erosion effects compared to common suspensions. Moreover, nanofluids show much higher thermal conductivity compared to the base fluid and usual suspensions (Amrollahi et al. 2007; Choi \& Eastman 1995; Keblinski et al. 2002; Wang \& Mujumdar 2007; Wang et al. 1999; Yu et al. 2008). There are many parameters that affect the nanofluids behavior such as size and shape of 
the particles, property of the base fluid and particles which are detailed in several studies (Ding et al. 2007; Liu et al. 2005; Zhang et al. 2007). However, the interactions among the various parameters have been neglected.

Besides, the stability of CNT based nanofluids is another major concern before utilizing in heat transfer equipment. It is reported that CNT based nanofluids are prone to sedimentation due to its hydrophobic nature, the high tendency of nanoparticles to agglomeration and its high aspect ratio (Garg et al. 2009; Hussein et al. 2013). In addition, other researchers (Ghadimi et al. 2011), specified that a durable and stable nanofluid is a key factor to achieve optimized thermal property performance. Ismail et al. (2016) investigated the rheological performance of multi walled carbon nanotudes in drilling fluids. They realized that applying xanthan gum with $0.2 \mathrm{wt} . \%$ as a surfactant improved rheological performance significantly (Ling et al. 2017) prepared non-Newtonian nanofluids by using xanthan gum $(0.2$ wt. \%) and multi walled CNTs in order to enhance the shell-side heat transfer coefficient of the helical baffled heat exchanger. Interestingly, XG $(0.2$ wt. \%) could improve heat transfer of multi walled carbon nanotubes. Also, Mahendran et al. (2012) reported that there is a relationship between stability and thermal conductivity of the carbon nanotube based nanofluids. Ponmani et al. (2014)xanthan gum (XG prepared copper oxide and zinc oxide nanofluids with the use of Xanthan gum as a dispersant to enhance stability. They exhibited that copper oxide in $0.4 \mathrm{wt}$. \% of xanthan gum was more stable than its counterpart.

In this present study, the focus was to enhance both the stability and thermal conductivity of CNT/water nanofluid. The stability of nanofluids is evaluated through visual method for duration of 2 months and also using UV vis spectroscopy method to determine the relative sedimentation with respect to time. $\mathrm{XG}$ is used as a surfactant to produce stable nanofluid samples. The thermal conductivity of nanofluids with the base fluid (water), XG solution and stable CNT nanofluids was investigated in this study.

\section{MATERIALS AND METHODS}

\section{EXPERIMENTAL DETAILS}

Multi-walled carbon nanotubes (MWCNTs) having an average O.D of 20-30 nm, I.D of, 5-10 nm, length of 10-30 $\mu \mathrm{m}$ and purity of $95 \%$ are obtained from Lab. Scientific, Malaysia. XG is obtained from the R \& M Marketing; Essex, U.K. Distilled water is used in this research. Figure 1 shows the molecular structure of xanthan gum.

\section{PREPARATION OF NANOFLUID}

CNT of known mass is dispersed in water along with the measured amount of XG. The resultant suspensions were sonicated using water bath sonicator (Elma Transsonic $\mathrm{TI}-\mathrm{H}-15$, USA) at $50^{\circ} \mathrm{C}$ temperature for $4 \mathrm{~h}$, frequency of $35 \mathrm{KHz}$. The sonication provides enough energy to detangle the CNT while the XG is adsorbed on the CNT surface preventing agglomeration and sedimentation. The diffusional rates and the frequency of collision between the individual tubes and XG molecule are achieved by sonication. It is important to know increased the temperature of water bath up to $80^{\circ} \mathrm{C}$ may change the properties of nanoparticles (Fadhillahanafi et al. 2013; Ponmani et al.2014). According to literature, the optimum duration to maximize the adsorption of dispersant on the CNT is $4 \mathrm{~h}$ sonication time at $35 \mathrm{kHz}$ (Rashmi et al. 2011). Also, reducing the aspect ratio of CNT and dislocation of carbon structure can be obtained by Prolonging sonication which will affect the thermal properties of CNT (O'Connell 2006).

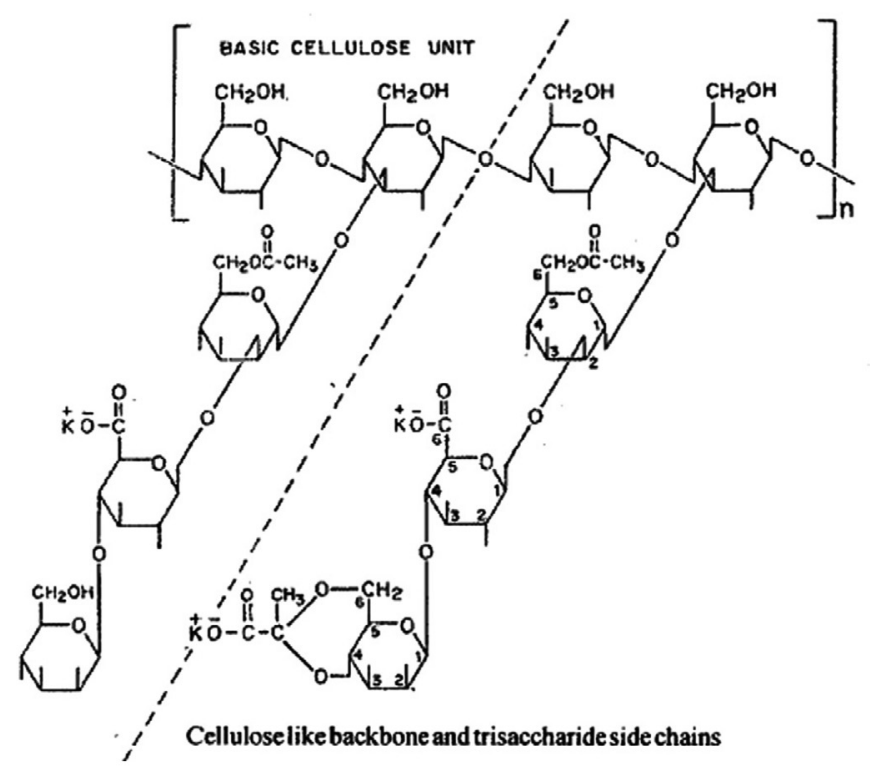

FIGURE 1. Molecular structure of xanthan gum (Palaniraj \& Jayaraman 2011) 


\section{CHARACTERIZATION}

\section{STABILITY}

The stability of the Nanofluids usually has been determined by using UV-VIS spectroscopy (Shimadzu UV-1800, Japan). In this technique, after sonication of nanofluids, approximately $3 \mathrm{~mL}$ of sample was transferred instantly into the cuvette cells. Distilled water is used as blank sample for baseline correction, while reference sample (water + respective $\mathrm{XG}$ ) was used to measure the CNT concentration with respect to time. Figure 2 clearly showed that the wavelength of CNT was $216 \mathrm{~nm}$, which is in concordance with the applicable wavelength of the cuvettes (210 to $900 \mathrm{~nm}$ ). Figure 3 demonstrates the absorbance value to carbon nanotube at various concentrations through the calibration curve. Based on the data in Figures 2 and 3 , the optimum XG concentration for each CNT can be obtained through the graph of CNT concentrations versus sedimentation time.

The stability studies were carried out for two months, in order to investigate the most stable nanofluids. CNT concentration was measured with sediment time using UV-Vis spectrophotometer and stable nanofluids were determined with respect to CNT and XG concentration.

\section{THERMAL CONDUCTIVITY}

The thermal conductivity was measured based on the standard transient hot-wire method by utilizing a KD2-Pro thermal analyzer (Decagon Devices, USA). The transient hot wire (THW) method is a transient dynamic technique based on the measurement of the temperature rise of a linear hot wire embedded in the tested material. The wire (platinum) serves both as the thermometer and heating element. For a good measurement, the KS-1 needle is

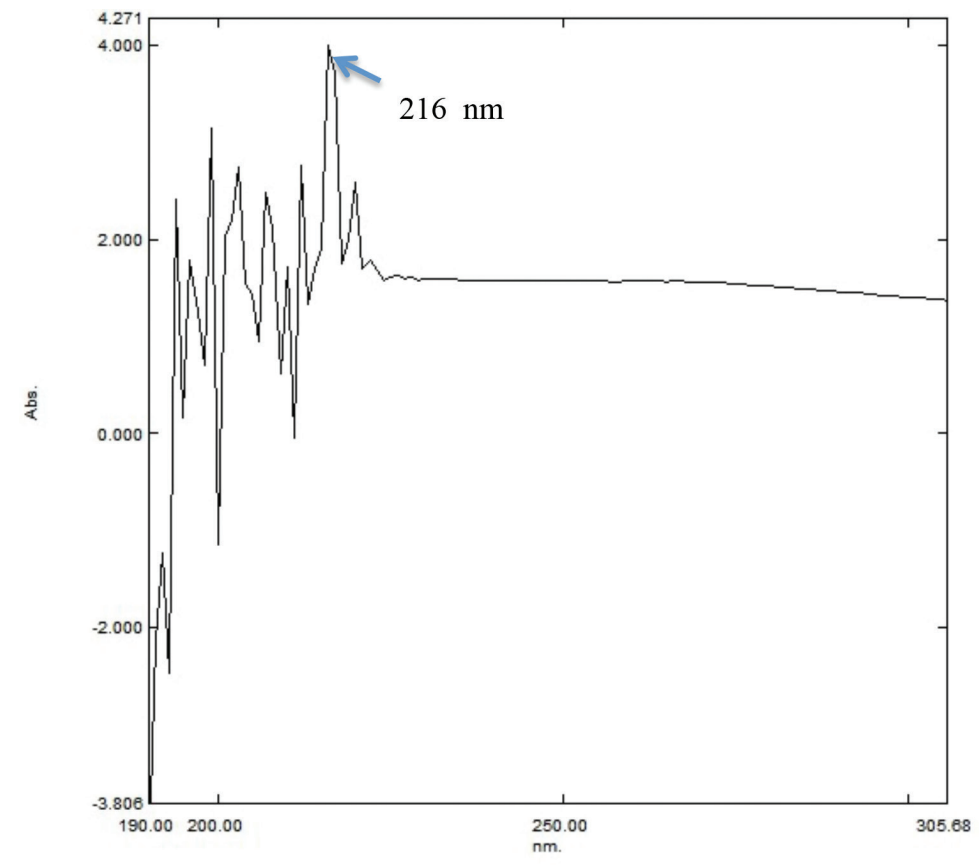

FIGURE 2. UV Vis absorption spectrum of CNT in water

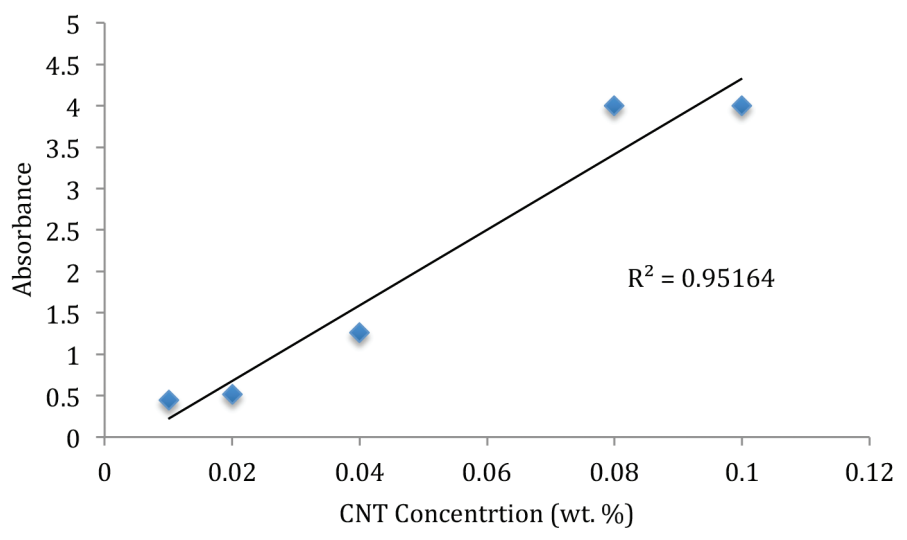

FIGURE 3. Calibration curve of light absorption and CNT concentration at $216 \mathrm{~nm}$ 
immersed in a homogeneous medium with uniform initial temperature, heated with a constant heat flux per unit length and then the temperature rise $\mathrm{T}(\mathrm{t})$ of the wire is measured. Before measuring the thermal conductivity, the device was calibrated with glycerin. In order to avoid any convection errors and effects, it is essential to observe some important points such as preparing a thermally and acoustically stable environment around the sample and dipping the probe vertically into the middle of the suspension. It is significant to note that the KD2-Pro has the ability to indicate the quality of the measurement via an error factor. In order to have reliable thermal conductivity value the error should be less than 0.01. All measurements were repeated 10 times then the average value was reported, in order to confirm a precise measurement. 4 sets of nanofluid and XG solutions for each dispersant individually with different amount of CNT, XG are prepared and shown in Table 1.

TABLE 1. Amount of CNT, XG and water used in nanofluid preparation

\begin{tabular}{cl}
\hline Samples & Contents \\
\hline 1 & Distilled water + 0.04 wt. \% XG \\
2 & Distilled water + 0.2 wt. \% XG \\
3 & CNT 0.01 wt. $\%+0.04$ wt. \% XG + Distilled water \\
4 & CNT 0.1 wt. $\%+0.2$ wt. \% XG + Distilled water \\
\hline
\end{tabular}

\section{SCANNING ELECTRON MICROSCOPY (SEM)}

In order to investigate the morphological structure of CNT and its interaction with XG dispersant, the SEM (FEI Quanta 400F, USA) test was carried out. A small amount of samples $(\mathrm{CNT} 0.01+\mathrm{XG} 0.04$ wt. \%) and (CNT $0.1+\mathrm{XG} 0.2$ wt. \%) were transferred into the petri dish and dried overnight in an oven at $100^{\circ} \mathrm{C}$ before it is observed under SEM.

\section{RESULTS AND DISCUSSION}

It is recognized that CNT cannot be dispersed homogeneously in aqueous solution and thus form aggregation due to Van der Waals forces of attraction. Thus, the optimum amount of dispersant plays vital role to stabilize the CNT in aqueous solution. Studies on XG have been clearly showed that this biopolymer has a great capability being used as a surfactant in preparation of nanofluids. In this study, XG behaves as a suitable dispersant in stabilizing the CNT in water by supplying sufficient repulsive force and minimizing the aggregation effect. Meanwhile, the sonication time, XG concentration and CNT concentration plays a key role in production of stable homogeneous nanofluids. Morphological and thermo-physical properties of CNT nanofluids are measured comprising thermal conductivity and stability behavior.

\section{STABILITY MEASUREMENTS}

From Figure 3 is can be seen that the $\mathrm{R}^{2}$ value for calibration curve which is defined as a determination coefficient, has a value of $>0.95$ which indicates a proper fit to the linear regression line. This is indicative of validity and reliability of stability results. Figures 4(a), 4(b), 5(a) and 5(b) demonstration the effect of XG concentration on stability of CNT dispersions. XG concentration is varied (0.04 and 0.2 wt. \%) for each CNT concentration (0.01 and 0.1 wt. $\%)$ and the results are plotted for $4.0 \mathrm{~h}$ sonication time.

From Figures 4(a), 4(b), 5(a) and 5(b), it is observed that the dispersant added to stabilize the suspension plays a very important role. CNT concentration in the suspension was measured with respect to sediment time to study the sedimentation rate of the nanofluids. Moreover, stabilization of nanofluid required the optimum amount of XG concentration. By increasing the concentration of CNT the respective XG concentration of also increases to adsorb onto the hydrophobic site in order to fully separate the individual tube during sonication. The optimum values of XG concentration were obtained for all the CNT concentrations. The optimum values of CNT and XG concentrations are $(0.01$ wt. $\%$ and 0.1 wt. $\%)$ and $(0.04$ and 0.2 wt. $\%)$, respectively. In addition, XG concentration below the optimum value was not adequate in exfoliating the thorough CNT agglomerates and hence caused sedimentation. It should be noted that, the additional amount of dispersant caused in self-agglomeration and form reverse micelles, therefore cannot adsorbed onto the CNT (Choi et al. 2008; Qi 2006). This study demonstrates that XG dispersant have ability to maintain the dispersion of CNT nanoparticles in the water by overcoming the Van der Waals or attractive forces between the neighboring tubes through steric repulsion. Table 2 shows the optimum XG concentration for each CNT concentration studied.

\section{THERMAL CONDUCTIVITY MEASUREMENTS}

Thermal conductivity of the base fluid (water), XG solution and stable CNT nanofluids have been measured at a CNT concentration of $0.01,0.1 \mathrm{wt} . \%$ and $\mathrm{XG}$ concentration of $0.04,0.2 \mathrm{wt}$ \% for temperature ranging from 25 to $70^{\circ} \mathrm{C}$ is shown in Figures 6 and 7, respectively.

The effect of temperature on CNT-XG nanofluid is investigated with respect to XG and CNT concentration, respectively. Thermal conductivity of water/XG solution is shown in Figure 6. It is observed that by increasing temperature and XG concentration, the thermal conductivity of base fluid decreased. This phenomenon occurs due to the lower thermal conductivity of $\mathrm{XG}(0.08 *$ $\left.10^{-1} \mathrm{~W} / \mathrm{mK}\right)$ compared to the water $\left(6 * 10^{-1} \mathrm{~W} / \mathrm{mK}\right)$. According to Figure 7 , by increasing temperature and CNT concentration, the thermal conductivity of the base fluid increased. This enhancement is more significant for higher CNT concentration $(0.1$ wt. $\%)$ at $50^{\circ} \mathrm{C}$. This is due to the Brownian motion of the nanoparticles where the nanoparticles are able to gain more kinetic energy at higher temperature. The CNT with high energy content will tend to move faster and bombard with each other, leading to a substantial increase in the thermal conductivity of nanofluids (Li et al. 2008). As Figures 6 and 7 demonstrated 


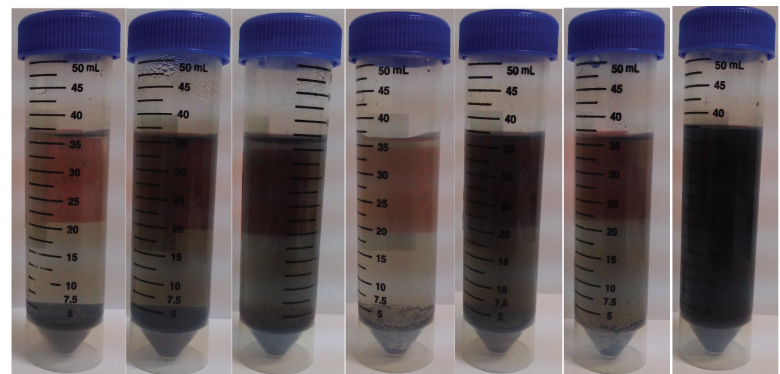

XG 0.01 wt. $\% 0.040 .080 .120 .160 .180 .2(\mathrm{~A})$

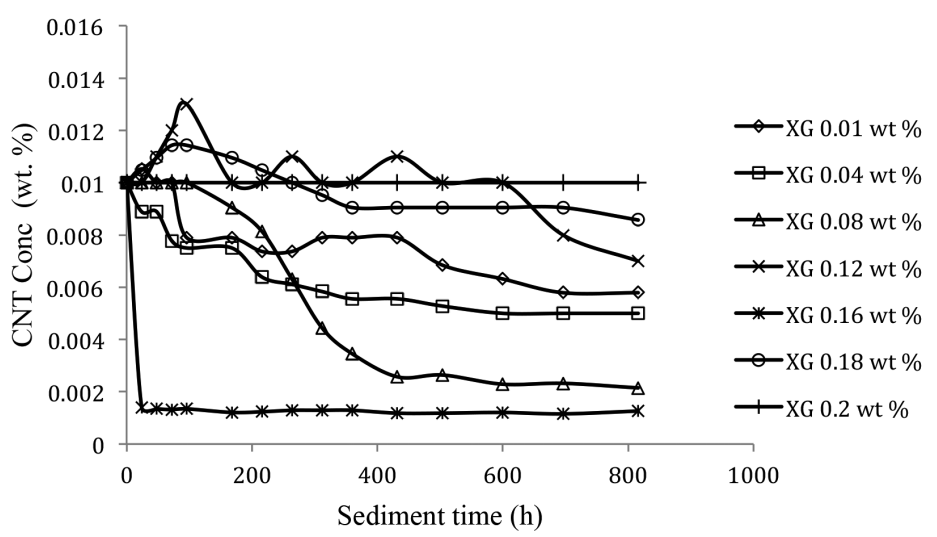

(B)

FIGURE 4. Effect of xanthan gum (XG) concentration on the stability of CNT: $0.01 \mathrm{wt}$ \% (a) sample images after $800 \mathrm{~h}$ of standing at a different XG concentration and (b) CNT concentration vs sediment time

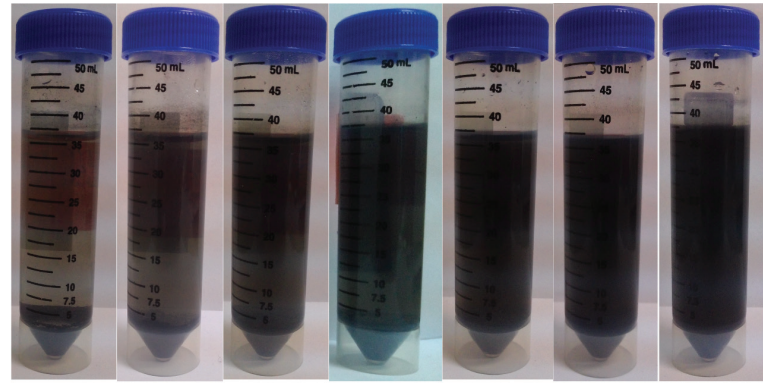

XG 0.01 wt. \% $0.040 .080 .120 .160 .180 .2(\mathrm{~A})$

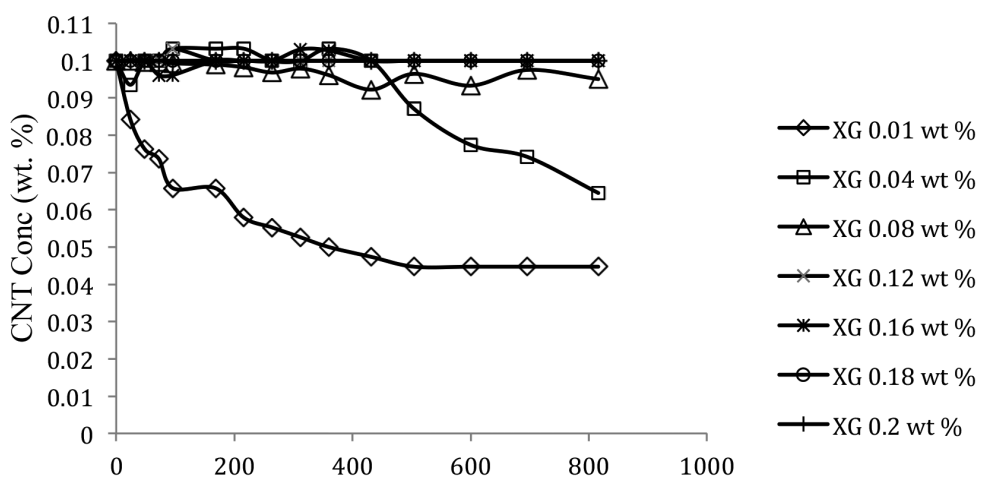

Sediment time (h)

(B)

FIGURE 5. Effect of xanthan gum (XG) concentration on the stability of CNT: 0.1 wt. \% (a) sample images after $800 \mathrm{~h}$ of standing at a different XG concentration and (b) CNT concentration vs. sediment time 
TABLE 2. Optimum values of XG concentration

\begin{tabular}{cc}
\hline $\begin{array}{c}\text { CNT concentration } \\
\text { (wt. \%) }\end{array}$ & $\begin{array}{c}\text { Optimum XG } \\
\text { concentration (wt. \%) }\end{array}$ \\
\hline 0.01 & 0.04 \\
0.1 & 0.2 \\
\hline
\end{tabular}

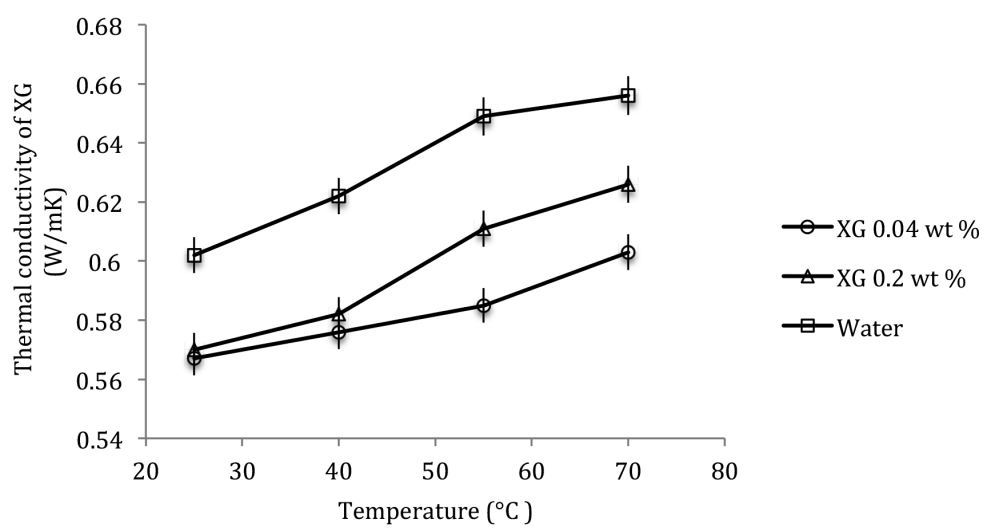

FIGURE 6. Effect of temp on thermal conductivity of XG solutions

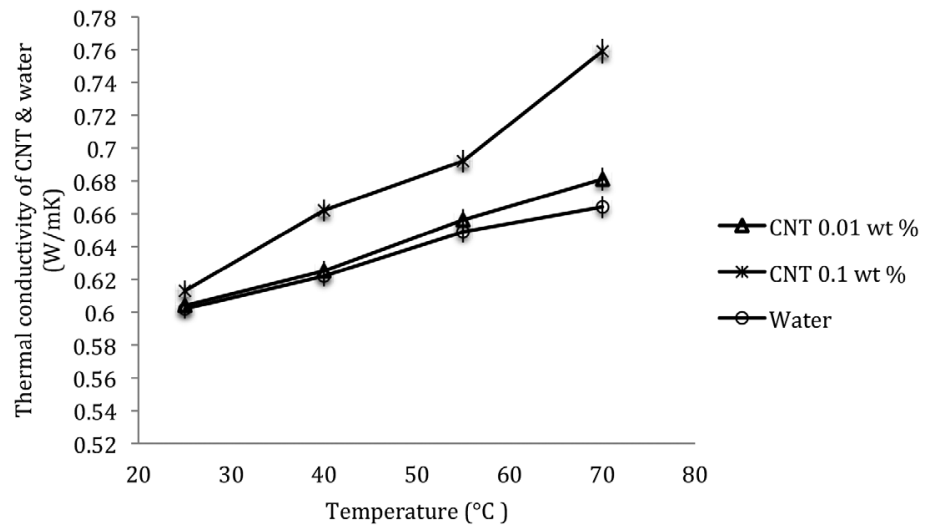

FIGURE 7. Effect of temp on thermal conductivity of CNT nanofluid 0.01 and 0.1 wt. \%

that CNT have remarkable influency on enhancing of thermal conductivity of water compared to XG alone. Rashmi et al. (2011) reported that Brownian motion of nanoparticles at the nanoscale and molecular level is a key mechanism governing thermal behavior of nanofluids, which is also a strong function of temperature. Therefore, it is clear from these figures that dispersant added to stabilize the nanoparticles in suspension does not have a significant role in thermal conductivity enhancement.

\section{SEM ANALYSIS}

The surface morphology of multi walled carbon nanotubes coated with biopolymer xanthan gum was characterized through SEM. Figure 8(a) and 8(b) illustrates the stable nanofluids with low (0.04 wt. \%) and high (0.2 wt. \%) concentration of biopolymer surfactant, respectively. It can be clearly seen, the surface of nanofluid with low concentration of surfactant was relatively rough which derived from the fact of nanoparticle nature and also incapability of surfactant to provide a good dispersity among nanofluids. As matter of the fact, due to high surface-to-volume of nanoparticles, they have a great capability to interact with their own molecules leading to self-agglomeration phenomena. Moreover, low concentration of surfactant could not cover the entire carbon nanotubes, consequently, rough surface with aggregated nanoparticles observed in Figure 8(a). However, further addition of surfactant not only decreases the self-interaction of nanoparticles but also cover entire nanoparticles; subsequently a smooth surface of nanofluid with good dispersity of nanoparticles illustrated in Figure 8(b). As a result, high concentration of surfactant was adequately ability to settle carbon nanotubes along with xanthan gum, implying the surfactant concentration is directly proportional to stability of nanofluids. It means 


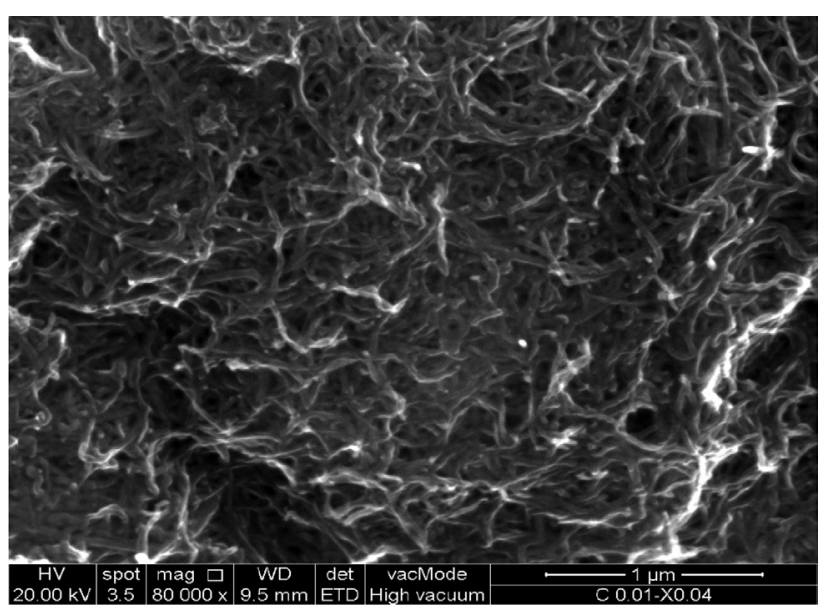

(a)

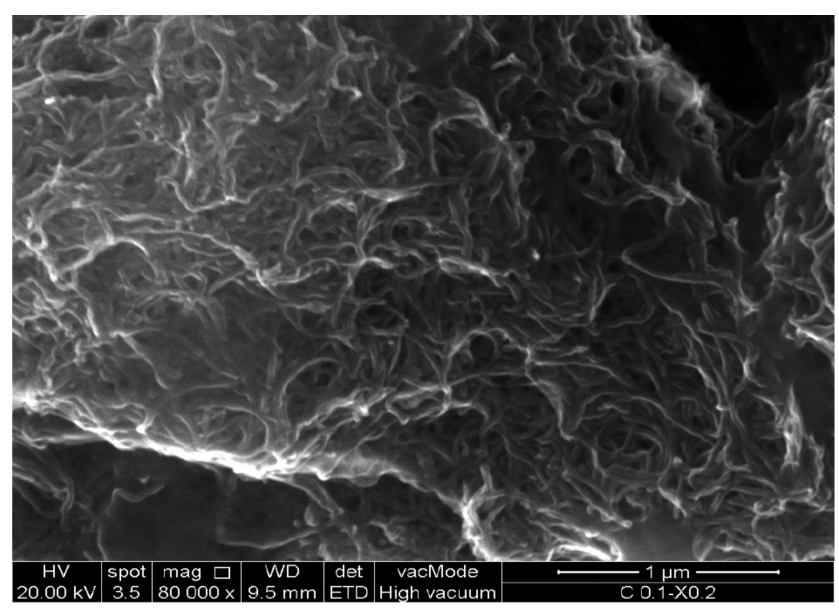

(b)

FIGURE 8. SEM images of nanofluids with difference concentrations of CNT, (a) 0.01 and (b) $0.1 \mathrm{wt} \%$

that, the increase in surfactant concentration leads to the increase in stability of suspension.

\section{CONCLUSION}

This present study investigated the effects of surfactant and nanoparticles concentrations on the stability as well as thermal conductivity of nanofluids. The UV-Vis and KD2Pro methods used to determine the stability and thermal conductivity of suspension nanofluids, respectively. High stability of nanofluids achieved, when the concentration of surfactant increased with the approval of SEM morphology. In nanofluid samples with 0.01 and 0.1 wt. \% carbon nanotubes, the optimum concentrations of surfactant were 0.04 and 0.2 wt. $\%$, respectively, to obtain the maximum stability. Whereas, the surfactant concentration influenced on thermal conductivity negligibly since the thermal conductivity of both concentrations were below the water. Interestingly, nanoparticle concentration due to its nature and also temperature raised the thermal conductivity.

\section{ACKNOWLEDGEMENTS}

One of the authors (Saba Rashidi) acknowledges the financial support from Universiti Putra Malaysia and MOHE, project no: UPM /700-2/1/FRGS/GSP/5524868.

\section{REFERENCES}

Amrollahi, A., Hamidi, A.A. \& Rashidi, A.M. 2007. Preparation of MCM-41 nanofluid and an investigation of Brownian movement of the nanoparticles on the nanofluid conductivity. International Journal of Nanoscience and Nanotechnology 3(1): 13-20.

Choi, C., Yoo,H.S. \& Oh, J.M. 2008. Preparation and heat transfer properties of nanoparticle-in-transformer oil dispersions as advanced energy-efficient coolants. Current Applied Physics 8(6): 710-712. doi:10.1016/j.cap.2007.04.060.

Choi, S.U.S. \& Eastman, J.A. 1995. Enhancing thermal conductivity of fluids with nanoparticles. ASME International
Mechanical Engineering Congress and Exposition 66: 99105. doi:10.1115/1.1532008.

Ding, Y., Chen, H., Wang, L., Yang, C.Y., He, Y., Yang, W., Lee, W.P., Zhang, L. \& Huo, R. 2007. Heat transfer intensification using nanofluids. KONA Powder and Particle Journal 25 (March): 23-38. doi:10.14356/kona.2007006.

Fadhillahanafi, N.M., Leong, K.Y.\& Risby, M.S. 2013. Stability and thermal conductivity characteristics of carbon nanotubes based nanofluids. International Journal of Automotive and Mechanical Engineering 8: 1376-1384.

Garg, P., Alvarado, J.L., Marsh, C., Calrson, T.A., Kessler, D.A. \& Annamalai, K. 2009. An experimental study on the effect of ultrasonication on viscosity and heat transfer performance of MWCNT based aqueous nanofluids. International Journal of Heat and Mass Transfer 52(May): 5090-5101.

Ghadimi, A., Saidur, R. \& Metselaar, H.S.C. 2011. A review of nanofluid stability properties and characterization in stationary conditions. International Journal of Heat and Mass Transfer 54(August): 4051-4068. doi:10.1016/j. ijheatmasstransfer.2011.04.014.

Hussein, A.M., Sharma, K.V., Bakar, R.A. \& Kadirgama, K. 2013. Heat transfer enhancement with nanofluids - a review. Journal of Chemical Information and Modeling 4(June): 452-461. doi:10.1017/CBO9781107415324.004.

Ismail, A.R., Wan Sulaiman, W.R., Jaafar, M.Z., Ismail, I. \& Sabu Hera, E. 2016. Nanoparticles performance as fluid loss additives in water based rilling fluids. Materials Science Forum 864: 189-193. doi:10.4028/www.scientific.net/ MSF.864.189.

Keblinski, P., Phillpot, R., Choi, S. \& Eastman, A. 2002. Mechanisms of heat flow in suspensions of nano-sized particles (Nanofluids). International Journal of Heat and Mass Transfer 45: 855-863.

Li, C.H., Williams, W., Buongiorno, J., Hu, L-W. \& Peterson, G.P. 2008. Transient and steady-state experimental comparison study of effective thermal conductivity of Al2O3-water nanofluids. Journal of Heat Transfer 130(4): 42407. doi:10.1115/1.2789719.

Ling, Z., He, Z., Xu, T., Fang, X., Gao, X. \& Zhang, Z. 2017. Experimental and numerical investigation on non-Newtonian nanofluids flowing in shell side of helical baffled heat 
exchanger combined with elliptic tubes. Applied Sciences 7(1): 48. doi:10.3390/app7010048.

Liu, M-S., Lin, M.C.C., Huang, I-T. \& Wang, C-C. 2005. Enhancement of thermal conductivity with carbon nanotube for nanofluids. International Communications in Heat and Mass Transfer 32(9): 1202-1210. doi:10.1016/j. icheatmasstransfer.2005.05.005.

Mahendran, M., Lee, G.C., Sharma, K.V. \& Shahrani, A. 2012. Performance evaluation of evacuated tube solar collector using water-based titanium oxide (TiO2) nanofluid. Journal of Mechanical Engineering and Sciences (JMES) 3: 301-310.

Maxwell, J.C. 1954. Summary for policymakers. A Treatise on Electricity and Magnetism 53(9): 1-30. doi:10.1017/ CBO9781107415324.004.

O'Connell, M.J. 2006. Carbon Nanotubes: Properties and Applications. Boca Raton: CRC Press.

Palaniraj, A. \& Jayaraman, V. 2011. Production, recovery and applications of xanthan gum by Xanthomonas campestris. Journal of Food Engineering 106(1): 1-12. doi:10.1016/j. jfoodeng.2011.03.035.

Ponmani, S,, William, J.K.M., Samuel, R., Nagarajan, R. \& Sangwai, J.S. 2014. Formation and characterization of thermal and electrical properties of $\mathrm{CuO}$ and $\mathrm{ZnO}$ nanofluids in xanthan gum. Colloids and Surfaces A: Physicochemical and Engineering Aspects 443: 37-43. doi:10.1016/j. colsurfa.2013.10.048.

Qi, L. 2006. Synthesis of inorganic nanostructures in reverse Micelles. Encyclopedia of Surface and Colloid Science 2: 6183-6207. doi:10.1081/E-ESCS-120023694.

Rashmi, W., Ismail, A.F., Sopyan, I., Jameel, A.T., Yusof, F., Khalid, M. \& Mubarak, N.M. 2011. Stability and thermal conductivity enhancement of carbon nanotube nanofluid using gum arabic. Journal of Experimental Nanoscience 6(6): 567-579. doi:10.1080/17458080.2010.487229.

Wang, X.Q.\& Mujumdar, A.S. 2007. Heat transfer characteristics of nanofluids: A review. International Journal of Thermal Sciences 46(1): 1-19. doi:10.1016/j.ijthermalsci.2006.06.010.

Wang, X., Xu, X. \& Choi, S.U.S. 1999. Thermal conductivity of nanoparticle-fluid mixture. Journal of Thermophysics and Heat Transfer 13(4): 474-480.

Yu, W., France, D.M. Routbort, J.L. \& Choi, S.U.S. 2008. Review and comparison of nanofluid thermal conductivity and heat transfer enhancements. Heat Transfer Engineering 29(5): 432-460. doi:10.1080/01457630701850851.

Zhang, X., Gu, H. \& Fujii, M. 2007. Effective thermal conductivity and thermal diffusivity of nanofluids containing spherical and cylindrical nanoparticles. Experimental Thermal and Fluid Science 31(6): 593-599. doi:10.1016/j. expthermflusci.2006.06.009.
Saba Rashidi*

Institute of Tropical Forestry and Forest Product

Universiti Putra Malaysia

43400 Serdang, Selangor Darul Ehsan

Malaysia

Rashmi, W.

Department of Chemical Engineering

Taylor's University

47500 Subang Jaya, Selangor Darul Ehsan

Malaysia

Luqman Chuah Abdullah

Materials Processing \& Technology Laboratory

Institute of Advanced Technology

Universiti Putra Malaysia

43400 Serdang, Selangor Darul Ehsan

Malaysia

Khalid, M.

Research Centre for Nano-Materials and Energy Technology Sunway University

No. 5, Jalan Universiti, Bandar Sunway

47500 Subang Jaya, Selangor Darul Ehsan

Malaysia

Fakhrul-Razi Ahmadun

Humanitarian Assistance and Disaster Relief Research Centre

National Defense University

Sungai Besi Camp

57000 Kuala Lumpur, Federal Territory

Malaysia

Faizah, M.Y,

Institute of Advanced Technology

Universiti Putra Malaysia

43400 Serdang, Selangor Darul Ehsan

Malaysia

*Corresponding author; email: Saba.rashidi604@gmail.com

Received: 17 October 2016

Accepted: 17 February 2017 